\title{
Rice Straw and Eggshell Ash as Partial Replacements of Cement in Concrete
}

\author{
Cyprian Oliko \\ Sustainable Materials Research and Technology Centre \\ Jomo Kenyatta University of Agriculture and Technology \\ Nairobi, Kenya \\ cyprianoliko@yahoo.com
}

\author{
Charles K. Kabubo \\ Sustainable Materials Research and Technology Centre \\ Jomo Kenyatta University of Agriculture and Technology \\ Nairobi, Kenya \\ kabcha@jkuat.ac.ke
}

\author{
John N. Mwero \\ Department of Civil Engineering \\ University of Nairobi \\ Nairobi, Kenya \\ johnmwero1@gmail.com
}

\begin{abstract}
This paper presents the properties of concrete made with cement partially replaced with rice straw ash and eggshell ash. The rice straws and eggshells were incinerated, sieved, and ground, and the physical and chemical properties of the resultant ash and the other materials incorporated in the concrete mixes were determined. A class 35 concrete mix with no partial replacement of cement with rice straw ash designed with the British Research Establishment method with a water/cement ratio of 0.5 was considered as the control mix. The cement in concrete was partially replaced with rice straw ash by $5 \%$ to $30 \%$ and its compressive and splitting tensile strength was determined after $7,14,28,56$, and 90 days of curing. Durability, resistance to acid attack, and other wet and hardened properties of concrete with cement partially replaced with rice straw ash were also determined. An increase in compressive strength above the control mix was observed for concrete with $5 \%$ and $10 \%$ partial replacement of cement with rice straw ash. When eggshell ash was added to concrete mixes made with cement partially replaced with rice straw ash at $15 \%$ and $20 \%$, the 28,56 , and 90 -day compressive strength was found to increase. It can be concluded that rice straw and eggshell ash can be used to partially replace cement in concrete and result in a concrete whose properties compare favorably with control.
\end{abstract}

Keywords-rice straw ash; eggshell ash; chemical composition; partial replacement; concrete compressive and splitting tensile strength; durability; water absorption

\section{INTRODUCTION}

Concrete is the most popular construction material. It may be used alone as mass concrete or with steel as reinforced or pre-stressed concrete $[1,2]$. Ordinary Portland Cement (OPC), which is the main component of various concrete types, is one of the most common construction materials worldwide. However, there is a global effort to utilize industrial or agricultural waste as raw materials for the concrete industry which will replace, at least partially, cement [3]. This has been inspired by economic, environmental, and technical reasons and aims at mitigating the environmental impact of concrete production and improving specific properties of the resultant concrete [4]. Pozzolans are materials which are not cementitious in nature but in processed forms react with water to form cementitious compounds in the presence of water lime [5]. Cement is manufactured from a mixture of calcium carbonate in form of limestone, silica iron oxide and alumina [6]. Four major compounds in cement are dicalcium silicate, tricalcium silicate, tricalcium aluminate and tetra-calcium aluminoferrite. Dicalcium silicate and tricalcium silicate are the compounds responsible for the strength of hydrated cement paste [7]. Upon wetting of cement the dicalcium silicate, tricalcium silicate and tricalcium aluminate react with water to form dicalcium silicate hydrate, tricalcium silicate hydrate $(\mathrm{C}$ $\mathrm{S}-\mathrm{H})$, calcium alumino silicate hydrate and tricalcium alumino ferrite hydrate. During the process, calcium hydroxide $\left(\mathrm{Ca}(\mathrm{OH})_{2}\right)$ is produced as a byproduct. The main strengthening compound is calcium silicate hydrate $(\mathrm{C}-\mathrm{S}-\mathrm{H})[8] . \mathrm{Ca}(\mathrm{OH})_{2}$ is responsible for the deterioration of concrete through leaching. When a pozzolanic material is added to Portland cement, the silica in it reacts with the $\mathrm{Ca}(\mathrm{OH})_{2}$ produced by cement hydration to produce additional calcium silicate hydrates and thus improves the cementitious properties [8-9].

The rice plant absorbs silica from the ground and assimilates in into its structure, so it is a good source of silica when appropriately incinerated [10]. Rice straw is available in large quantities from rice irrigation schemes at negligible cost. Chicken eggshells are normally considered as waste and are thrown away. They are available in large quantities from hatcheries and confectioneries. Their main component is calcium carbonate $\left(\mathrm{CaCO}_{3}\right)$ with magnesium, potassium, sodium, phosphorus, aluminum, zinc and copper found in small proportions [11]. During the incineration of the eggshells, the $\mathrm{Ca}(\mathrm{CO})_{3}$ decomposes to form $\mathrm{CaO} /$ lime and $\mathrm{CO}_{2}$. The $\mathrm{CO}_{2}$ will escape while the $\mathrm{CaO}$ will remain in the ash [12]. Therefore,

Corresponding author: Cyprian Oliko 
eggshells are a suitable, eco-friendly and sustainable alternative to quarry limestone.

From the reviewed literature, it has been observed that at higher percentages of partial replacement of cement with pozzolans, there is a decrease in the compressive strength of concrete, due to the high silica and low $\mathrm{CaO}$ content in the pozzolans. Higher percentages of partial replacement of cement with pozzolanic ash result in a reduction in the quantity of available $\mathrm{CaO}$ in the mix which is required to react with silica to form calcium silicate hydrates that are responsible for concrete's strength. This deficit can be remedied by the addition of eggshell ash. This study aimed at establishing the effect of partial replacement of cement in concrete with rice straw ash and eggshell ash on concrete strength and the extent to which rice straw ash and eggshell ash can partially replace cement in concrete.

\section{METHODOLOGY}

\section{A. Materials}

\section{1) Rice Straw Ash}

Oryza Sativa (Basmati) rice straws were used in this study and were collected from Bunyala rice irrigation scheme, Busia County, Kenya. The straws were dried and then incinerated at $650^{\circ} \mathrm{C}$ for $1 \frac{1}{2}$ hours [13]. The ash was successively sieved through $600 \mu \mathrm{m}, 425 \mu \mathrm{m}$ BS, and finally $75 \mu \mathrm{m}$ BS sieves. The resultant ash was further ground in a ball mill for 4 minutes. Only particles passing the above sieves were used for partial cement replacement [14]. Chemical analysis of the ash was done with an X-ray diffractometer at the Mines and Geology laboratory in Nairobi. Particle size distribution was done on the ash by hydrometer analysis.

\section{2) Eggshell Ash}

The eggshells used were obtained from small scale hatcheries and hotels. They were cleaned to remove impurities, dried in the sun until their surface became dry and incinerated at $900^{\circ} \mathrm{C}$ for 2 hours. The resultant ash was ground in a ball mill for 4 minutes. Chemical analysis of the ash was done by an X-ray diffractometer at the Mines and Geology laboratory in Nairobi.

\section{3) Aggregates}

River sand obtained from Malaba River in Western Kenya was used as fine aggregates and crushed stone obtained from Sirikwa quarry in Eldoret, Uasin Gishu county, Kenya as coarse aggregates.

\section{4) Cement}

The cement used in this study was OPC type CEM 1- class $42.5 \mathrm{~N}$ to Kenya Standard (KS EAS 18-1:2001). Chemical analysis was also done on the cement.

\section{B. Concrete Mix Proportions}

The concrete mix design used in this research was done according to Building Research Establishment (BRE) method with target strength of $35 \mathrm{~N} / \mathrm{mm}^{2}$ at 28 days. Rice straw ash was used to replace cement at $5,10,15,20,25$, and $30 \%$ by weight of cement. A water/cement ratio of 0.5 was used for all the mixes. Fifteen concrete cubes and 15 cylinders were made for each mix ratio. The wet properties of the resultant concretes were determined immediately after mixing. The concrete was cast in $150 \times 150 \times 150 \mathrm{~mm}$ cubes and $150 \mathrm{~mm}$ diameter and $300 \mathrm{~mm}$ height cylinders that were demoulded after 24 hours and cured in water for $7,14,28,56$, and 90 days. The hardened concrete properties were determined from the cast cubes and cylinders.

\section{CONCRETE TESTS}

\section{A. Slump Test}

Slump tests were conducted on wet concrete to BS 1881 Part 102(1983).

\section{B. Compaction Factor Test}

Compaction factor tests were conducted on cement pastes with various \% partial replacement of cement to Indian Standard 1199:1959.

\section{Compressive Strength Test}

The cast cubes were crushed in a compressive strength testing machine according to BS 1881Part 116(1983).

\section{Split Tensile Strength Test}

Split tensile strength tests were conducted on the concrete cylinders in a compressive strength testing machine according to the BS 1881Part 117(1983).

\section{E. Durability Test}

Concrete cube specimens cured for 56 days were immersed in $0.5 \%$ dilute sulphuric acid. They were tested for residual compressive strength in a compressive strength testing machine.

\section{RESUltS AND DISCUSSION}

\section{A. Material Properties}

Table I illustrates the chemical composition of rice straw ash and OPC. In Table I, we notice that the main chemical oxides in cement composition were within the tolerances specified by the Kenyan standard for cement KS EAS 18$1: 2001$. The results of rice straw ash indicate that the rice straw ash was found to be composed of $72.379 \% \mathrm{SiO}_{2}$ (silica) by weight. From Table I it can be observed that the combined percentage of silica and alumina is $74.34 \%$ which satisfies the $70 \%$ minimum specified by ASTM C 618 [15] for a material to be used as a pozzolan. The chemical composition of eggshell ash is shown in Table II. It can be observed that eggshell ash consists of $96.755 \% \mathrm{CaO}$. In comparison, Portland cement consists of $72.04 \% \mathrm{CaO}$.

It can be observed in Figure 1 that the particles of rice straw were to have smaller size than those of cement since they recorded higher passing percentage than cement for all sieve sizes.

\section{B. Setting Time}

The setting time test results on cement pastes are illustrated in Figure 2. 
TABLE I. CHEMICAL ANALYSIS OF CEMENT AND RICE STRAW ASH

\begin{tabular}{|c|c|c|c|}
\hline \multicolumn{3}{|c|}{ OPC } & \multirow{2}{*}{$\begin{array}{c}\text { Rice straw ash } \\
\text { Percentage }\end{array}$} \\
\hline Component & Percentage & $\begin{array}{c}\text { Tolerance (KS EAS } \\
18-1: 2001)\end{array}$ & \\
\hline MgO & 0.000 & & 0.000 \\
\hline $\mathrm{Al}_{2} \mathrm{O}_{3}$ & 4.076 & $3 \%-8 \%$ & 1.094 \\
\hline $\mathrm{SiO}_{2}$ & 14.18 & $17 \%-25 \%$ & 72.379 \\
\hline $\mathbf{P}_{2} \mathbf{0}_{5}$ & 0.857 & & 1.513 \\
\hline $\mathbf{S}$ & 4.303 & & 0.919 \\
\hline $\mathrm{Cl}$ & 0.138 & $0 \%-5 \%$ & 1.450 \\
\hline $\mathrm{K}_{2} \mathrm{O}$ & 0.746 & & 16.174 \\
\hline $\mathrm{CaO}$ & 72.041 & $60 \%-67 \%$ & 5.067 \\
\hline $\mathbf{T i}$ & 0.222 & & 0.100 \\
\hline $\mathbf{V}$ & 0.003 & & 0.006 \\
\hline $\mathrm{Cr}$ & 0.001 & & 0.006 \\
\hline Mn & 0.057 & & 0.256 \\
\hline $\mathbf{F e}$ & 3.087 & & 0.836 \\
\hline Co & 0.000 & & 0.000 \\
\hline $\mathbf{N i}$ & 0.000 & & 0.002 \\
\hline $\mathrm{Cu}$ & 0.004 & & 0.013 \\
\hline Zn & 0.005 & & 0.080 \\
\hline As & 0.000 & & 0.000 \\
\hline So & 0.000 & & 0.000 \\
\hline $\mathbf{R b}$ & 0.004 & & 0.070 \\
\hline $\mathrm{Sr}$ & 0.204 & & 0.021 \\
\hline $\mathbf{Y}$ & 0.003 & & 0.000 \\
\hline $\mathbf{Z r}$ & & & 0.007 \\
\hline Nb & & & 0.003 \\
\hline Total & 99.973 & & 99.996 \\
\hline
\end{tabular}

TABLE II. CHEMICAL ANALYSIS OF EGGSHELL ASH

\begin{tabular}{|c|c|c|}
\hline Component & Percentage & Standard deviation \\
\hline $\mathrm{CaO}$ & $96.755 \%$ & 0.173 \\
\hline $\mathrm{K}_{2} \mathrm{O}$ & $2.523 \%$ & 0.116 \\
\hline $\mathrm{SrO}$ & $0.606 \%$ & 0.006 \\
\hline $\mathrm{SO}_{3}$ & $0.116 \%$ & 0.006 \\
\hline Total & $100 \%$ & \\
\hline
\end{tabular}

PSD of Cement \& Rice Straw Ash vs Sieve Size

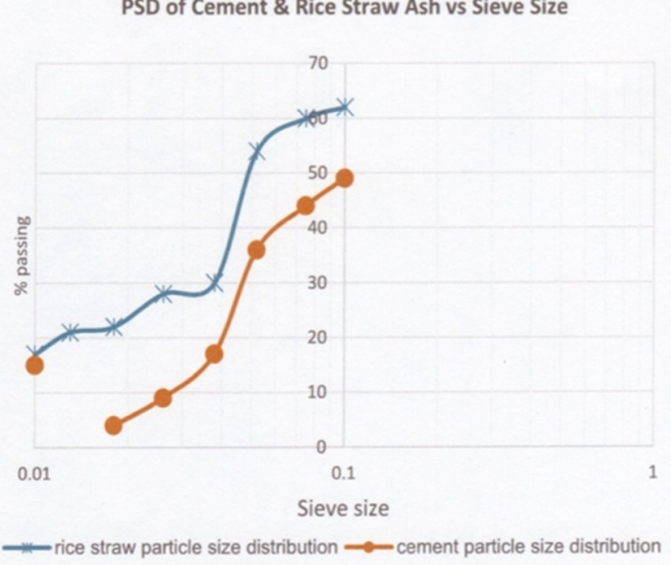

Fig. 1. Particle size distribution of cement and rice straw ash vs sieve size.

The initial and final setting times of concrete with $5-30 \%$ partial replacement of cement with rice straw were found to range between 85 and 615 minutes compared to the control which recorded an initial setting time of 65 minutes and a final setting time of 495 minutes. Two main factors affecting setting time in cement are chemical composition and fineness. It can be observed that as the partial replacement of cement with rice straw increased, the initial and final setting time also increased. Both initial and final setting time of concrete depend on chemical reactions that take place in cement. $\mathrm{Al}_{2} \mathrm{O}_{3}$ present in cement is responsible for the formation of tricalcium aluminate which aids the quick hardening of cement. From the chemical analysis of the cement in Table I, it can be observed that cement was found to contain $4.076 \% \mathrm{Al}_{2} \mathrm{O}_{3}$, while the rice straw ash was found to contain $1.094 \% \mathrm{Al}_{2} \mathrm{O}_{3}$. Thus the partial replacement of cement with rice straw ash led to a reduction in in $\mathrm{Al}_{2} \mathrm{O}_{3}$, hence the setting times for cement pastes with rice straw ash was increased.

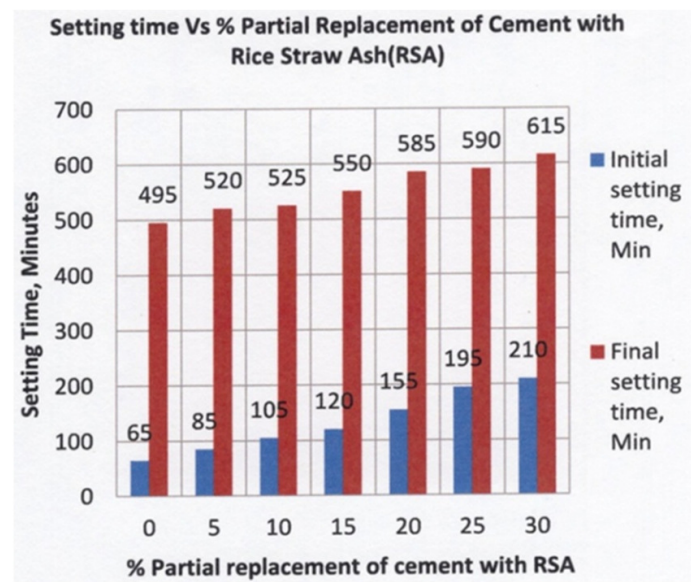

Fig. 2. Setting time vs partial replacement of cement with rice straw ash.

\section{Slump}

The slump values for concrete with various percentages of partial replacement of cement with rice straw ash are exhibited in Table II and Figure 3.

TABLE III. SLUMP VALUES FOR VARIOUS PERCENTAGES OF PARTIAL REPLACEMENT OF CEMENT IN CONCRETE

\begin{tabular}{|c|c|c|c|c|c|c|c|}
\hline & \multicolumn{6}{|c|}{ \% Partial replacement of cement with rice straw ash\% } \\
\hline & 0 & 5 & 10 & 15 & 20 & 25 & 30 \\
\hline Slump, mm & 62 & 51 & 47 & 39 & 10 & 0 & 0 \\
\hline
\end{tabular}

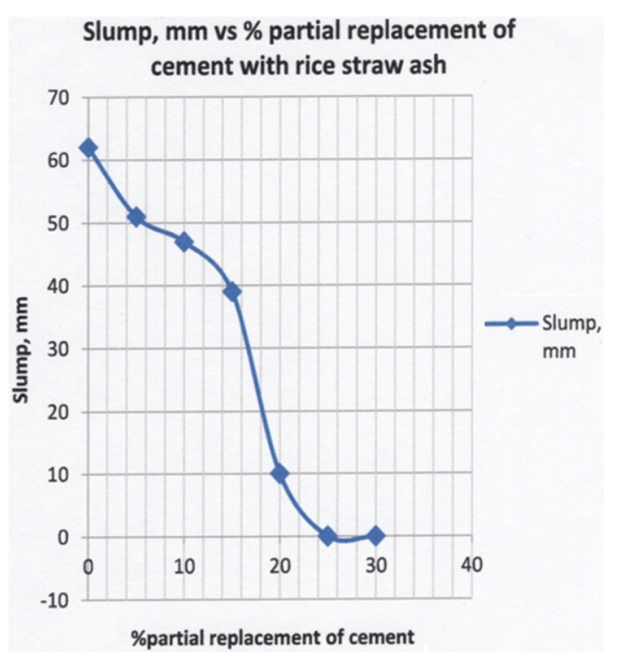

Fig. 3. Slump vs percentage of partial replacement of cement in concrete. 
The results in Table III and Figure 3 indicate a steady decline in the slump value with increase in partial percentage replacement of cement with rice straw ash. The control mix had the highest slump of $62.0 \mathrm{~mm}$ while concrete mixes with $25 \%$ and $30 \%$ partial cement replacement were found to have zero slump. Thus, with increase in rice straw ash, the concrete became less workable. These findings are consistent with those of [13]. This reduction in consistency can be attributed to the additional water requirement caused by the smaller particle sizes of rice straw ash which also have porous surfaces, hence increased surface area.

\section{Compaction Factor}

The results of the compaction factor tests are presented in Table IV.

TABLE IV. COMPACTION FACTOR FOR CEMENT/RICE STRAW PASTES

\begin{tabular}{|c|c|c|c|c|c|c|c|}
\hline & \multicolumn{6}{|c|}{ \% Partial replacement of cement with rice straw ash\% } \\
\hline & 0 & 5 & 10 & 15 & 20 & 25 & 30 \\
\hline $\begin{array}{c}\text { Compaction } \\
\text { factor (\%) }\end{array}$ & 0.685 & 0.680 & 0.674 & 0.668 & 0.666 & 0.654 & 0.622 \\
\hline
\end{tabular}

It can be observed that as the percentage of partial replacement of OPC with rice straw ash increases, the workability and hence the compaction factor of concrete decreases. This occurs because when the cement is replaced with an equal mass of rice straw ash, this leads to an increase in both the volume of mass due to the lower relative density of rice straw ash. The increased mass leads to increased number of particles and hence specific surface area due to the fact that the rice straw ash is less dense than the cement. This increase in surface area leads to increased water demand by the rice straw ash in the mix. This additional water demand reduces the water available for the workability of concrete and hence the workability decreases since the water to cement ratio was unchanged for all the mixes. Comparing the results in Table III and Table IV, it can be observed that the compaction factor is more sensitive than slump test for stiffer concretes.

\section{E. Compressive Strength}

In Figure 4 we can notice an increase in compressive strength above the control for concrete mixes with 5\% and $10 \%$ partial cement replacement for all the ages of testing. The 7, 14, 28,56 , and 90 days compressive strength was found to be $27.90,33.00,35.95,36.55$, and 38.70 for the control mix while the compressive strength was found to be $32.70,36.70,38.80$, 40.25 , and 41.30 representing $17.2 \%, 11.2 \%, 7.9 \%, 10.1 \%$, and $6.7 \%$ increase above the control respectively for $5 \%$ partial cement replacement. For $10 \%$ partial replacement of cement the strength was found to be $33.65,37.10,40.20,41.80$, and 42.65 for $7,14,28,56$, and 90 days representing $20.6 \%$, $12.42 \%, 11.8 \%, 14.3 \%$, and $10.2 \%$ increase above the control respectively. The increase in concrete strength can be attributed to two factors: First, the filler effect of pozzolanic material which has smaller particles than cement resulted in denser packing of particles within the concrete matrix and at the aggregate/concrete interface. The second is the pozzolanic reaction between the silica in and $\mathrm{Ca}(\mathrm{OH})_{2}$ produced by cement hydration which occurs after the hydration reaction and is responsible for strength gain during the later days of concrete curing. For mixes with partial cement replacement of 15, 20, 25 , and $30 \%$, a drop in compressive strength below the control was observed. The $7,14,28,56$, and 90 day compressive strengths were found to be $28.70,31.60,32.30,33.70$, and 34.70 respectively for $15 \%$ partial cement replacement and $28.40,29.55,31.80,32.60$, and 33.45 respectively for $20 \%$ partial cement replacement. For $25 \%$ partial cement replacement the strengths were found to be $24.00,26.20,28.70$, 31.85 , and 32.80 while for $30 \%$ partial cement replacement the compressive strength was found to be $10.85,15.25,18.95$, 20.05 , and 23.10 for $7,14,28,56$, and 90 days curing age respectively.

Since the rice straw ash was found to have a $\mathrm{CaO}$ : Silica ratio of $1: 14.3$ instead of the recommended $3: 13$ and a $\mathrm{CaO}$ content of $5.07 \%$ instead of the recommended $61-67 \%$ (Table I), the partial replacement of cement with rice straw leads to a reduction in $\mathrm{CaO}$ and an increase in silica. At low percentages of replacement, the silica reacts with the $\mathrm{CaO}$ released by the hydration of cement to form cementitious materials. At higher replacement levels of cement, there is an increase in the amount of pozzolan in the concrete mix however the replacement of cement with pozzolan has an effect of reducing the cement content in the concrete which in turn reduces the quantity of released $\mathrm{Ca}(\mathrm{OH})_{2}$ by hydration of $\mathrm{OPC}$. This reduction in $\mathrm{Ca}(\mathrm{OH})_{2}$ production leads to the reduced production of the cementitious product $(\mathrm{C}-\mathrm{S}-\mathrm{H})$ that is responsible for the strength development in concrete. The optimum percentage of partial replacement of cement with rice straw ash was found to be $10 \%$, in which there is equilibrium and all the $\mathrm{Ca}(\mathrm{OH})_{2}$ produced by the cement hydration reaction combines with silica to form calcium silicate hydrates(C-S-H). Beyond the optimum $10 \%$ of partial replacement of cement there is less $\mathrm{Ca}(\mathrm{OH})_{2}$ produced by the cement hydration reaction, hence there is a reduced opportunity for $\mathrm{Ca}(\mathrm{OH})_{2}$ to react with silica to form additional $\mathrm{C}-\mathrm{S}-\mathrm{H}$. To reduce this deficit in $\mathrm{CaO}$ and facilitate continuation of the silica $\mathrm{Ca}(\mathrm{OH})_{2}$ pozzolanic reaction, eggshell ash was added to the concrete mix in order to react with silica to form additional C$\mathrm{S}-\mathrm{H}$ and mitigate the strength loss of the concrete at higher partial replacement levels of cement with rice straw ash.

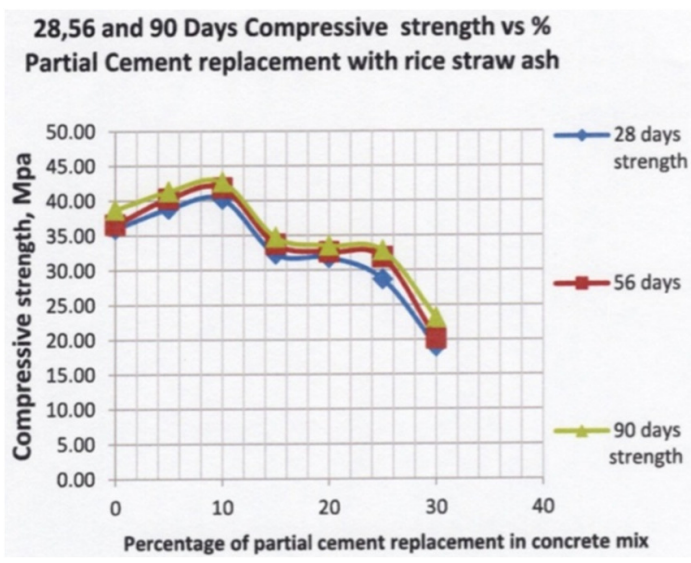

Fig. 4. Compressive strength vs the percentage of partial replacement of cement with rice straw ash in concrete. 
Figures 5, 6, and 7 illustrate the 28, 56, and 90 days compressive strength of concrete with various percentages of partial replacement of cement with rice straw ash and concrete with partial replacement of cement with both rice straw and eggshell ash.

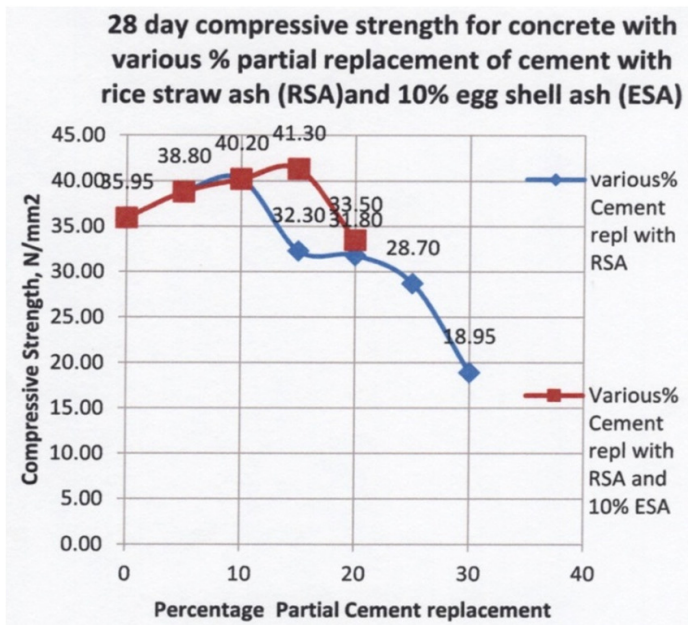

Fig. 5. 28-day compressive strength for concrete with various percentages of partial replacement of cement with rice straw ash and eggshell ash.

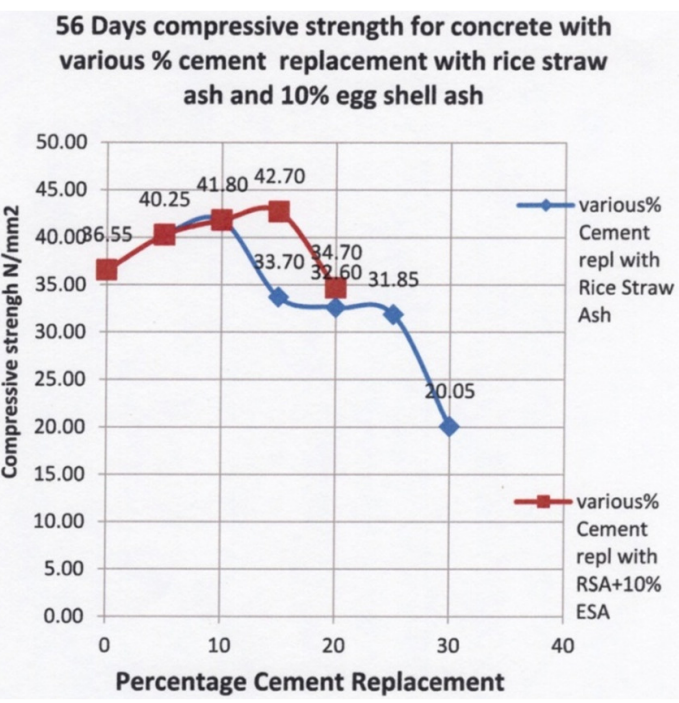

Fig. 6. 56-day compressive strength for concrete with various percentages of partial replacement of cement with rice straw ash and eggshell ash.

From the compressive strength results, concretes with $15 \%$ and above partial replacement of cement with rice straw ash exhibited decrease in their strength. The 28, 56, and 90 days compressive strength of concrete with $15 \%$ partial cement replacement with rice straw ash and $0 \%$ eggshell ash were found to be $32.3,33.7$, and $34.7 \mathrm{~N} / \mathrm{mm}^{2}$ while the compressive strength for concrete with $15 \%$ partial cement replacement with rice straw ash and $10 \%$ eggshell ash was $41.3,42.7$, and 44.85 representing strength increase of $25.3 \%, 26.7 \%$ and $29.2 \%$ respectively. On the other hand the 28,56 , and 90 days compressive strength for concrete with $20 \%$ partial cement replacement with rice straw ash and $0 \%$ eggshell ash was found to be $31.8,32.6$ and $33.8 \mathrm{~N} / \mathrm{mm}^{2}$ while the compressive strength for concrete with $20 \%$ partial cement replacement with rice straw ash and $10 \%$ eggshell ash was $33.5,34.7$ and $34.85 \mathrm{~N} / \mathrm{mm}^{2}$ representing strength increase of $5.34 \%, 3.26 \%$, and $3.88 \%$ respectively.

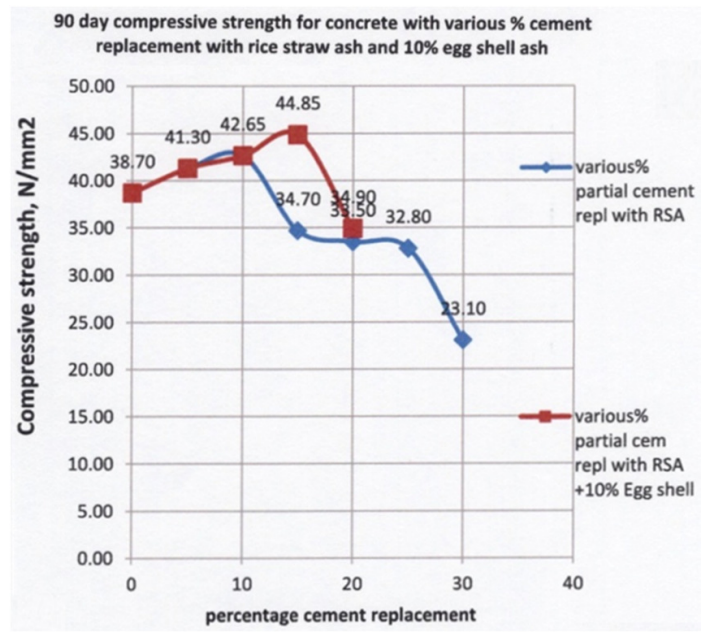

Fig. 7. 90-day compressive strength for concrete with various percentages of partial replacement of cement with rice straw ash and eggshell ash.

Previous researchers reported a decrease in compressive strength at higher levels of partial replacement of cement in concrete with pozzolans. There is limited information on what can be done to remedy the concrete strength loss at higher partial cement replacement levels and still take advantage of the silica present in the pozzolans. None of the reviewed researches proposed a remedy. In the current research, eggshell ash was added to concrete mixes with higher partial replacement levels of cement with rice straw ash. Eggshell ash, rich in $\mathrm{CaO}$ reduced the $\mathrm{CaO}$ deficit occasioned by replacing cement with rice straw ash owing to their dissimilar chemical composition. This ensured that even at higher cement replacement levels with rice straw ash, $\mathrm{CaO}$ was available to react with silica from the pozzolan and form additional calcium silicate hydrates that are responsible for strength. This increased the concrete strength that had been initially recorded before the addition of eggshell ash as illustrated by the above results. Thus, the objective of reducing the content of cement and the cost of concrete was achieved.

\section{F. Splitting Tensile Strength}

Figure 8 illustrates the variation of splitting tensile strength with the percentage partial replacement of cement with rice straw ash for various ages of curing. It can be observed that the splitting tensile strength for $5 \%$ and $10 \%$ replacement was found to be above the control. For $15 \%, 20 \%, 25 \%$, and $30 \%$ partial replacement, the splitting tensile strength was found to be lower than the control's. Thus, for both compressive and splitting tensile strength, it can be said that $10 \%$ partial cement replacement in concrete is the optimum. Beyond 10\% partial replacement, the compressive strength decreases with the increase in replacement percentage. 


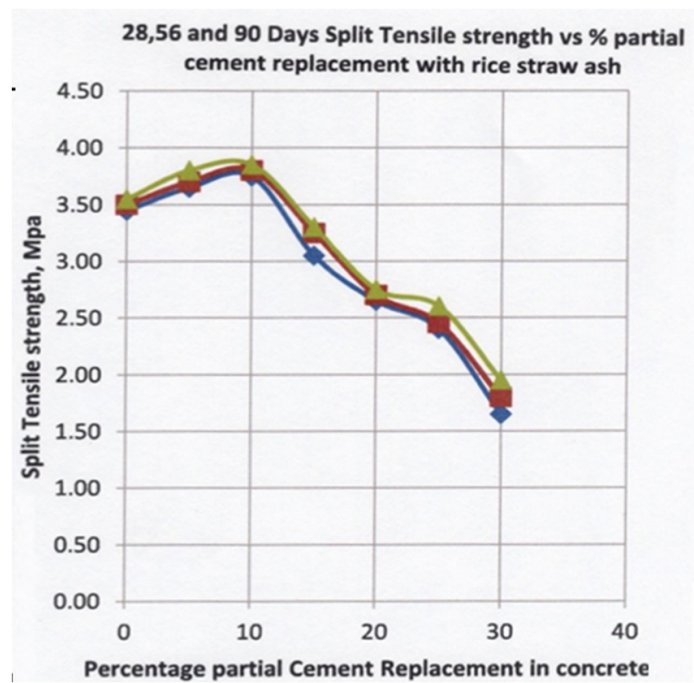

Fig. 8. Splitting tensile strength vs percentage of partial replacement of cement with rice straw ash in concrete.

\section{G. Accelerated Durability Test}

The test results on concrete cubes cured for 56 days in water and immersed in bath containing $0.5 \%$ dilute sulphuric acid for 30 days are exhibited in Table V.

TABLE V. MASS LOSS OF VARIOUS CONCRETE MIXES IMMERSED IN $0.5 \%$ SULPHURIC ACID

\begin{tabular}{|c|c|c|c|}
\hline $\begin{array}{c}\text { Concrete } \\
\text { Mix }\end{array}$ & $\begin{array}{c}\text { Mass before } \\
\text { immersion (g) }\end{array}$ & $\begin{array}{c}\text { Mass after } \\
\text { immersion (g) }\end{array}$ & $\begin{array}{c}\text { Change } \\
\text { percentage }\end{array}$ \\
\hline $\begin{array}{c}\text { 0\% Partial } \\
\text { replacement }\end{array}$ & 8,529 & 8,443 & -1.01 \\
\hline $\begin{array}{c}10 \% \text { Partial } \\
\text { replacement }\end{array}$ & 8,353 & 8,329 & -0.29 \\
\hline
\end{tabular}

In Table $\mathrm{V}$ it is noticed that the control recorded the highest mass loss of $1.01 \%$, while the concrete cubes with $10 \%$ (optimum) partial cement replacement with rice straw ash recorded the least loss in mass $(0.29 \%)$ which is very close. The mass loss in concrete cube specimens can be attributed to the formation of gypsum, part of which dissolved in the solution and part appeared as a precipitate in the acid solution bath. Sulphuric acid $\left(\mathrm{H}_{2} \mathrm{SO}_{4}\right)$ reacts with $\mathrm{Ca}(\mathrm{OH})_{2}$ in the concrete matrix to form gypsum which is soluble [16]. For the specimen with no partial replacement of cement with rice straw ash, the $\mathrm{Ca}(\mathrm{OH})_{2}$ that was formed by the hydration reaction reacts with sulphuric acid to form gypsum. These specimens did not have a pozzolan in their mixes to consume the $\mathrm{Ca}(\mathrm{OH})_{2}$ formed by hydration hence there was greater opportunity for the reaction between $\mathrm{Ca}(\mathrm{OH})_{2}$ and $\mathrm{H}_{2} \mathrm{SO}_{4}$ to occur and form gypsum. They also lacked the packing effect of pozzolan particles in their concrete matrix to prevent percolation of acid solution into the concrete cube matrix. These factors could explain why they recorded the highest mass loss on exposure to acid solution. On the other hand, in the specimens with $10 \%$ partial replacement of cement with rice straw ash, the $\mathrm{Ca}(\mathrm{OH})_{2}$ formed during hydration was consumed by the pozzolanic reactions with silica in the rice straw ash to form additional calcium silicate hydrates, hence reduced the opportunity for the reaction that leads to the formation of gypsum and thus reducing mass loss.

TABLE VI. COMPRESSIVE STRENGTH OF VARIOUS CONCRETE MIXES IMMERSED IN $0.5 \%$ SULPHURIC ACID

\begin{tabular}{|c|c|c|c|}
\hline $\begin{array}{c}\text { Concrete } \\
\text { Mix }\end{array}$ & $\begin{array}{c}\text { Compressive } \\
\text { strength before } \\
\text { immersion } \\
\text { (MPa) }\end{array}$ & $\begin{array}{c}\text { Compressive } \\
\text { strength after } \\
\text { immersion (MPa) }\end{array}$ & $\begin{array}{c}\text { Change } \\
\text { percentage }\end{array}$ \\
\hline $\begin{array}{c}\text { 0\% Partial } \\
\text { replacement }\end{array}$ & 38.7 & 36.47 & -5.77 \\
\hline $\begin{array}{c}10 \% \text { Partial } \\
\text { replacement }\end{array}$ & 42.65 & 41.1 & -3.56 \\
\hline
\end{tabular}

We can see in Table VI that the control mix without partial replacement of cement with rice straw ash had the highest reduction in compressive strength at $5.77 \%$ while the mix with $10 \%$ partial replacement was found to have a compressive strength reduction of $3.56 \%$. Rice straw particles were found to be smaller in particle size than those of cement, as illustrated by Figure 1, thus the concrete with partial replacement of cement with rice straw ash achieved denser packing of particles making them less porous to capillary penetration of the acid solution. The impregnating effect of rice straw ash along with the formation of additional calcium silicate hydrates by the pozzolanic reaction filled voids in the concrete matrix and enhanced the chemical resistance and capillary penetration of the acid solution in the concrete matrix and hence slowed its corrosion effect leading to reduced mass loss.

\section{CONCLUSIONS}

- The studied rice straw ash meets the requirements of ASTM C 618 specifications for pozzolans.

- The rice straw ash can partially replace OPC in concrete up to an optimum percentage of $10 \%$. The concrete compressive strength was found to increase by $11.8 \%$, $14.3 \%$, and $10.2 \%$ above control for 28,56 , and 90 days of curing.

- Eggshell ash used in this study was found to be composed of $96.75 \% \mathrm{CaO}$ when incinerated. The eggshell ash can be used in combination with rice straw ash to increase the strength of concrete with higher percentage of partial replacement of cement with rice straw ash that otherwise recorded a decrease in strength .

- The optimum combination of eggshell ash and rice straw ash to be used together to partially replace cement in concrete was found to be $10 \%$ for both.

- The rice straw ash was found to increase the resistance of the concrete to the acid solution, hence it can be used for concretes exposed to acidic environment and sulphate attacks.

- Concrete with cement partially replaced with rice straw ash was found to have lower capillary water absorption and hence improved durability. 


\section{RECOMMENDATIONS}

\section{A. Recommendations for Use}

- Rice straw ash can be used to partially replace cement in concrete up in percentages up to $10 \%$.

- Rice straw ash can be used to make concrete in environments that are susceptible to acid attack

- Eggshell ash can be used in combination with rice straw ash to partially replace cement and enable higher partial replacement of cement with pozzolans with reduced loss of concrete strength.

\section{B. Recommendations for Further Research}

- Varying the water cement ratio above or below 0.5 and compare the properties of concrete with the ones found in the current study.

- Obtaining rice straw from other irrigation schemes and using the ash for partial replacement of cement in concrete and compare the properties of concrete with the ones found in the current study.

- Incinerating the ashes at different temperatures and durations from those used in this study.

\section{REFERENCES}

[1] C. M. Ikumapayi, "Properties of groundnut shell (Arachis hypogaea) ash blended portland cement," Journal of Applied Sciences and Environmental Management, vol. 22, no. 10, pp. 1553-1556, Nov. 2018, https://doi.org/10.4314/jasem.v22i10.3.

[2] F. A. Olutoge, H. A. Quadri, and O. S. Olafusi, "Investigation of the Strength Properties of Palm Kernel Shell Ash Concrete," Engineering, Technology \& Applied Science Research, vol. 2, no. 6, pp. 315-319, Dec. 2012, https://doi.org/10.48084/etasr.238.

[3] R. Srinivasan and K. Sathiya, "Experimental study on bagasse ash in concrete," International Journal for Service Learning in Engineering, Humanitarian Engineering and Social Entrepreneurship, vol. 5, no. 2, pp. 60-66, Oct. 2010, https://doi.org/10.24908/ijsle.v5i2.2992.

[4] S. A. Chandio, B. A. Memon, M. Oad, F. A. Chandio, and M. U. Memon, "Effect of Fly Ash on the Compressive Strength of Green Concrete," Engineering, Technology \& Applied Science Research, vol. 10, no. 3, pp. 5728-5731, Jun. 2020, https://doi.org/10.48084/etasr.3499.

[5] J. Manasseh, "A Review of Partial Replacement of Cement with Some Agro Wastes," Nigerian Journal of Technology, vol. 29, no. 2, pp. 1220, 2010, https://doi.org/10.4314/njt.v29i2.

[6] N. Amin, "Study of the Physical Parameters of Ordinary Portland Cement of Khyber Pakhtoon Khwa Pakistan and their comparison with Pakistan standard Specifications," Chemical Engineering Research Bulletin, vol. 14, no. 1, pp. 7-10, May 2010, https://doi.org/10.3329/cerb.v14i1.3729.

[7] M. S. Ali, I. A. Khan, and M. I. Hossain, "Chemical Analysis of Ordinary Portland Cement of Bangladesh," Chemical Engineering Research Bulletin, vol. 12, pp. 7-10, 2008, https://doi.org/10.3329/cerb.v12i0.1491.

[8] L. Ettu, C. Njoku, C. Awodiji, A. Amanze, and M. Arimanwa, "Variation of OPC-Rice Husk Ash-Saw Dust Ash Composites Strength with Mix Proportion," International Journal of Engineering Sciences \& Research Technology, vol. 2, no. 8, pp. 1964-1969, Aug. 2013.

[9] K. A. Kassim and K. K. Chern, "Lime stabilized Malaysian cohesive soils," Jurnal Kejuruteraan Awam, vol. 16, no. 1, pp. 13-23, 2004.

[10] N. M. Chanu and T. K. Devi, "Contribution of rice husk ash to the properties of cement mortar and concrete," International Journal of Engineering Research and Technology, vol. 2, no. 2, 2013.
[11] H. A. Rathod and J. Pitroda, "A Study of Future Trend for Sustainable Development by Incorporation of SCM's," International Journal of Scientific Research, vol. 2, no. 2, pp. 110-115, Feb. 2013.

[12] M. O. A. Mtallib and A. Rabiu, "Effect of Egg Shell Ash (ESA) on Setting Time of Cement," Nigerian Journal of Technology, vol. 28, no. 2, pp. 29-38, Sep. 2009.

[13] S. Munshi, G. Dey, and R. Prasad Sharma, "Use of Rice Straw Ash as Pozzolanic Material in Cement Mortar," International Journal of Engineering and Technology, vol. 5, no. 5, pp. 603-606, Oct. 2013, https://doi.org/10.7763/IJET.2013.V5.626.

[14] A. E. Abalaka, "Strength and Some Durability Properties of Concrete Containing Rice Husk Ash Produced in a Charcoal Incinerator at Low Specific Surface," International Journal of Concrete Structures and Materials, vol. 7, pp. 287-293, 2013, https://doi.org/10.1007/s40069013-0058-8.

[15] C09 Committee, "Specification for Coal Fly Ash and Raw or Calcined Natural Pozzolan for Use in Concrete," ASTM International. Accessed: Nov. 22, 2020. [Online]. Available: http://www.astm.org/cgibin/resolver.cgi?C618-19.

[16] B. M. Reddy, H. S. Rao, and M. P. George, "Effect of sulphuric acid (H2SO4) on blended cement (fly ash based) and its concrete," International Journal of Applied Engineering and Technology, vol. 2, no. 2,2012 . 